\title{
Sweetpotato Tip Rot Incidence Is Increased by Preharvest Applications of Ethephon and Reduced by Curing
}

\author{
Ramón A. Arancibia ${ }^{1,3}$, Jeffrey L. Main ${ }^{1}$, and Christopher A. Clark ${ }^{2}$
}

AdDitionAl INDEX WORDs. Ipomoea batatas, ethylene, devining, end rot

Summary. Tip rot, or restricted end rot, is a new sweetpotato (Ipomoea batatas) disease/disorder in Mississippi with unknown etiology. Since pathogen isolations have been inconsistent, a relationship of this disorder with stress is proposed. This disease/disorder is manifested as a restricted lesion at or close to the proximal end of the storage root and appears after 2 to 4 weeks in storage. In many cases, the lesion necrosis expands internally. On-farm and research station studies with preharvest foliar applications of ethephon were conducted in Mississippi to determine the potential association of tip rot with ethephon-induced stress. In addition, the effects of ethephon rate and interval between application and harvest on tip rot were investigated. After 1 to 2 months in storage, tip rot incidence was observed mostly in storage roots from ethephon-treated plants. The increase in tip rot incidence was well correlated with ethephon rate. These results suggest that preharvest applications of ethephon trigger a response that results in the tip rot disorder.

$\mathrm{T}$ ip rot, or restricted end rot, is a sweetpotato disease/disorder with unknown etiology that has caused recent problems in Mississippi and possibly other production areas. Symptoms appear after 2 to 4 weeks in storage resulting in significant losses. In general, postharvest rots reduce pack-out efficiency, which affects profitability, but the internal necrosis associated with tip rot can go unnoticed until consumer use, which affects quality perception, and therefore, diminishes demand. Pathogen isolations have been inconsistent with this disorder: different pathogens and nonpathogens were isolated while in some cases nothing was isolated from lesions (da Silva and Clark, 2012; Stokes et al., 2012). Therefore, a relationship with stress has been suggested. Ethylene is produced in plants under stress/injury and a previous

This work was funded by the USDA-NIFA Specialty Crop Research Initiative grant number 2009-5118106071 and the Mississippi Sweet Potato Council.

The authors acknowledge the assistance of Lori B. Grelen and Xiang Wang.

Mention of a trademark, proprietary product, method, or vendor does not imply endorsement by Mississippi State University and does not imply its approval to the exclusion of other products or vendors that also may be suitable.

${ }^{1}$ Pontotoc Ridge-Flatwoods Branch Experiment Station, North Mississippi Research and Extension Center, Mississippi State University, 8320 Highway 15 South, Pontotoc, MS 38863

${ }^{2}$ Department of Plant Pathology and Crop Physiology, Louisiana State University Agricultural Center, 302 Life Science Building, Baton Rouge, LA 70803

${ }^{3}$ Corresponding author. E-mail: raa66@msstate.edu. study has indicated that preharvest foliar applications of ethephon enhance the incidence of a similar disorder in North Carolina (Dittmar et al., 2010). This suggests that ethephoninduced stress may be influencing the incidence of this disorder.

Sweetpotato is one of the leading vegetable crops grown in Mississippi with over 24,000 acres planted in 2011 (U.S. Department of Agriculture, 2012). However, profitability can be affected significantly with $20 \%$ to $25 \%$ postharvest losses because of diseases, shrinkage, and loss of quality (Edmunds et al., 2008). Postharvest deterioration is usually the most economically costly stage for growers to lose marketable product because all the expenses of production, harvesting, and storage have already been incurred. In Mississippi, pack-out losses attributed to tip/end rots have increased dramatically during the last 6 years contributing to significant reductions in production efficiency and profitability (B. Graves, personal communication). In a survey of 15 packinghouses, losses due to tip/end rots were estimated at $6 \%$ to $59 \%$ (W. Burdine, unpublished data). Therefore, understanding the factors influencing tip/end rot incidence is necessary to develop proper management strategies.

Tip rot is manifested at or close to the proximal end of the storage root as a small sunken and irregular lesion delimited by a sharp border (Fig. 1). The lesion is usually shallow and progresses onto storage roots asymmetrically, but in some cases necrosis expands internally with little or no external symptoms. Tip rot is distinct from other nonrestricted or moderately aggressive fungal end rots caused by known pathogens (Clark, 1992; Clark et al., 2013) that are referred to as end rots in this study (Fig. 1). The margin of the lesion of nonrestricted end rots are not sharply defined, and the lesion is usually deep (spans the storage root) and progresses onto the storage root symmetrically.

Tip rot incidence in Mississippi has been observed more frequently when dry conditions prevail before harvest. There is also evidence that preharvest applications of ethephon and other defoliants used in potato (Solanum tuberosum) induce physiological changes in sweetpotato storage roots resulting in skin set and reduced skinning at harvest (Schultheis et al., 2000). Since ethylene plays an important role in stress responses and induces senescence in plants (Abeles et al., 1992), we hypothesize that preharvest applications of ethephon triggers physiological responses that may result in the tip rot disorder. Therefore, the objective of this study is to determine whether there is an association of tip rot incidence in sweetpotato with ethephon-induced stress before harvest.

\section{Materials and methods}

ETHEPHON-INDUCED STRESS. The incidence of tip (restricted) and end (nonrestricted) rot in response to

\begin{tabular}{llll}
\hline $\begin{array}{l}\text { Units } \\
\text { To convert U.S. to SI, } \\
\text { multiply by }\end{array}$ & U.S. unit & SI unit & $\begin{array}{l}\text { To convert SI to U.S., } \\
\text { multiply by }\end{array}$ \\
\hline 0.4047 & $\mathrm{acre}(\mathrm{s})$ & $\mathrm{ha}$ & 2.4711 \\
0.3048 & $\mathrm{ft}$ & $\mathrm{m}$ & 3.2808 \\
9.3540 & gal/acre & $\mathrm{L} \cdot \mathrm{ha}^{-1}$ & 0.1069 \\
2.54 & inch $(\mathrm{es})$ & $\mathrm{cm}$ & 0.3937 \\
0.4536 & $\mathrm{lb}$ & $\mathrm{kg}$ & 2.2046 \\
70.0532 & $\mathrm{oz} / \mathrm{acre}$ & $\mathrm{g} \cdot \mathrm{ha}^{-1}$ & 0.0143 \\
$\left({ }^{\circ} \mathrm{F}-32\right) \div 1.8$ & ${ }^{\circ} \mathrm{F}$ & ${ }^{\circ} \mathrm{C}$ & $\left({ }^{\circ} \mathrm{C} \times 1.8\right)+32$
\end{tabular}


preharvest foliar application of ethephon was evaluated in Mississippi during 2010 and 2011. Four commercial fields in three counties and three commercial fields in two counties were selected in 2010 and 2011 , respectively (Table 1). Additional field trials were conducted at the Pontotoc Ridge-Flatwoods Experiment Station (Pontotoc, MS) each year to add an extra field and production condition to the study. The soil types included Falkner silt loam, Bude silt loam, and Adaton silt loam (Table l). 'Beauregard' (B-14) sweetpotato was chosen for these studies because it is the main variety cultivated in Mississippi. Planting dates varied from field to field, but all were planted in June. Plant spacing was 42 inches between rows and 16 inches or 18 inches within row depending on location. Trials followed production practices according to each particular farmer. At the experiment station, plant spacing was $40 \times 12$ inches and followed standard production practices (Thompson et al., 2002). The experimental unit or plot consisted of four $20-\mathrm{ft}$ rows. Treatments consisted in preharvest foliar

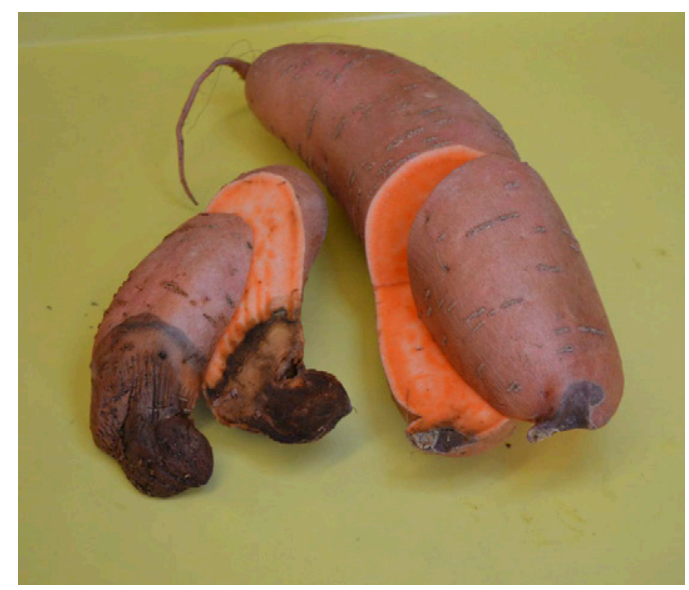

Fig. 1. Symptoms of end rot (nonrestricted) (storage root on the left) and tip rot (restricted) (storage root on the right) in 'Beauregard' (B-14) sweetpotato. In nonrestricted end rot, the margin of the lesion is not sharply defined and the lesion is usually deep (spans the storage root) and progresses onto the storage root symmetrically. Tip rot is manifested at or close to the proximal end of the storage root as a small sunken and irregular lesion delimited by a sharp border. The lesion is usually shallow and progresses into the storage root asymmetrically, but in some cases necrosis expands internally with little or no external symptoms.

application of ethephon (Prep; Bayer CropScience, Research Triangle Park, $\mathrm{NC})$ at 12 and/or $24 \mathrm{oz} /$ acre a.i. depending on location and compared with nontreated control. Ethephon was applied $\mathrm{l}$ to $7 \mathrm{~d}$ before harvest $(\mathrm{DBH})$, depending on location (Table 1), with a four-row boom sprayer calibrated to $20 \mathrm{gal} / \mathrm{acre}$. Time of treatment before harvest was based on the time of defoliation/devining before harvest practiced in each field. However, for these trials, all treatments and nontreated control were defoliated/devined at harvest with a two-row flail mower/ deviner (model FB-080; United Farm Tools, South Charleston, WV). Harvest date also varied for different fields and extended from late Aug. to late Sept. 2010 and to mid Oct. 2011 (Table 1). Harvested roots (74 to 151 marketable storage roots per plot) from the middle two rows were stored without curing at $65^{\circ} \mathrm{F}$ and $70 \%$ to $80 \%$ relative humidity ( $\mathrm{RH}$ ) for 1 to 2 months until evaluation for tip and end rot incidence. Restricted and nonrestricted symptoms in storage roots were determined visually, and the incidence of tip and end rots was determined by the percentage of roots with restricted and nonrestricted symptoms, respectively. The experimental design for each field was randomized complete block with four replications (plots).

E THEPHON RA TE AN D APPLICATION TIME. The association of tip and end rot incidence with

Table 1. Field location, soil type, treatments, and harvest dates for the on-farm and research station trials to evaluate the effect of ethephon-induced stress and curing on the incidence of sweetpotato tip rot disorder in Mississippi.

\begin{tabular}{|c|c|c|c|c|c|c|c|}
\hline$\underline{\text { Yr }}$ & Field location $^{\mathrm{z}}$ & County & Soil type & $\begin{array}{c}\text { Ethephon rate } \\
(\text { oz/acre })^{\mathrm{y}}\end{array}$ & $\begin{array}{l}\text { Treatment time } \\
(\mathrm{DBH})^{\mathrm{x}}\end{array}$ & Harvest date & Curing test ${ }^{\mathrm{w}}$ \\
\hline \multirow[t]{5}{*}{2010} & Field trials & & & & & & \\
\hline & Bellefontaine & Webster & Bude & 0,24 & 5 & 7 Sept. & \\
\hline & Road 33 & Chickasaw & Falkner & $0,12,24$ & 3 & 24 Aug. & \\
\hline & Vardaman 1 & Calhoun & Falkner & 0,24 & 1 & 24 Aug. & \\
\hline & Vardaman 2 & Calhoun & Adaton & $0,12,24$ & 3 & 24 Aug. & Yes \\
\hline & Res. Station 2 & Pontotoc & Adaton & $0,12,24,36$ & $1,3,7$ & 7 Oct. & \\
\hline 2011 & Field trials & & & & & & \\
\hline & Houlka & Chickasaw & Falkner & $0,12,24$ & 3 & 29 Aug. & Yes \\
\hline & Vardaman 1 & Calhoun & Adaton & $0,12,24$ & 5 & 12 Sept. & Yes \\
\hline & Vardaman 2 & Calhoun & Adaton & $0,12,24$ & 5 & 15 Sept. & Yes \\
\hline & Res. Station & Pontotoc & Bude & 0,24 & 7 & 17 Oct. & \\
\hline
\end{tabular}

${ }^{\mathrm{z}}$ Res. Station $=$ Research Station

${ }^{\mathrm{y}} \mathrm{l} \mathrm{oz} /$ acre $=70.0532 \mathrm{~g} \cdot \mathrm{ha}^{-1}$.

${ }^{x}$ Days before harvest when treatments were applied

wHarvest from selected fields were used for curing study. 
ethephon rate and application time before harvest was investigated further in a different experiment at the Pontotoc research station (Table 1 ). 'Beauregard' (B-14) sweetpotato was grown in an Adaton soil type following standard production practices (Thompson et al., 2002). Each experimental unit (plot) consisted of four $20-\mathrm{ft}$ rows and the middle two rows were harvested for evaluation. Plant spacing was 40 inches between rows and 12 inches within row. Treatments consisted in preharvest defoliation/ devining (ethephon rate at $0 \mathrm{oz} / \mathrm{acre}$ ) with a two-row flail mower/deviner (described above) and applications of ethephon at rates of 12,24 , and $36 \mathrm{oz} / \mathrm{acre}$. Treatment time for defoliation/devining and ethephon applications were at 1,3 , and $7 \mathrm{DBH}$. Ethephon-treated plots and one additional untreated control were defoliated/devined as described above on the day of harvest. The times of treatment before harvest were selected based on practices sweetpotato growers in Mississippi use for defoliating/devining before harvest to set the skin and reduce skinning at harvest. Experimental design was a split plot with four replications: defoliation/devining and ethephon rates as the main plots and $\mathrm{DBH}$ as subplots. Trial was harvested on 7 Oct. 2010 and roots were stored without curing at $65{ }^{\circ} \mathrm{F}$ and $70 \%$ to $80 \%$ RH for 2 months until evaluation. Tip and end rot incidence was determined as described above.

Curing. The incidence of tip and end rots was evaluated after curing in comparison with noncured storage roots. Two field trials in 2010 and three field trials in 2011 with yields above 3 bushels $(150 \mathrm{lb})$ of marketable roots per plot were selected for the curing test (Table 1 ). A 1-bushel $(50 \mathrm{lb})$ sample (52 to 67 roots) from each ethephon-treated plot (four plots per treatment) was cured immediately at $85^{\circ} \mathrm{F}$ and $80 \%$ to $85 \% \mathrm{RH}$ in a walk-in growth chamber for $7 \mathrm{~d}$. After curing, samples were stored with the noncured samples for 1 to 2 months until evaluation for tip and end rot incidence as described above.

All data analysis, regression and correlation to determine differences among treatments and the association between ethephon rates and rot incidence, respectively, were done using SAS (version 9.2; SAS Institute, Cary, $\mathrm{NC})$. Incidence data are presented in percentage, but it was transformed [arcsine (square root)] for statistical analysis to stabilize the variances.

\section{Results and discussion}

ETHEPHON-INDUCED STRESS. Ethephon is an ethylene generating product that has been used in agriculture for several decades to promote responses regulated by ethylene (Abeles et al., 1992). Leaf senescence (yellowing, browning, and defoliation) is the first response to foliar applications of ethephon in sweetpotato and other plants. Senescing is a genetically programmed process in which cells undergo metabolic changes conducive to cell structure degradation, nutrient remobilization, and ending in cell death (Lim et al., 2007). The senescing response in sweetpotato was rate dependent. At low rate $(12 \mathrm{oz} /$ acre), yellowing and leaf drop were predominant and lasted 5 to $6 \mathrm{~d}$. At $36 \mathrm{oz} /$ acre, symptoms developed faster and stronger: leaves turned yellow, then brown and dropped within $4 \mathrm{~d}$. Although there has been no study to determine translocation of ethephon down to the roots when applied to sweetpotato foliage, there is evidence of translocation in other crops (Abeles et al., 1992; Edgerton and Hatch, 1972), in some cases limited (Young and Jahn, 1975), that appears to follow a source-sink movement. This suggests that ethephon may reach the roots when foliage has been sprayed and therefore, ethylene may be inducing stress responses in the roots that could be influenced by concentration.

Tip rot was observed mainly in storage roots from ethephon-treated plants (Table 2). The incidence among fields ranged between $0.7 \%$ and $4.7 \%$, and between $1.6 \%$ and $13.8 \%$ at ethephon rates of 12 and $24 \mathrm{oz} /$ acre, respectively. Vardaman 1 in 2011 was the only field with a significant incidence of tip rot $(4.6 \%)$ in the nontreated control. Although not all fields had significant differences between roots from treated and nontreated plants, when fields were pooled together for 2010, 2011, and for both years, there were significant differences and well correlated $(r=0.54,0.78$, and 0.60 , respectively) with ethephon rate. These results indicate that postharvest tip rot incidence increased in response to preharvest foliar applications of ethephon and support the hypothesis that ethephon-induced stress triggers responses conducive to the tip rot disorder. Tip rot incidence in storage roots from ethephon-treated plants

Table 2. Percent incidence of tip rot (restricted end rot) in sweetpotato roots in response to preharvest foliar applications of ethephon in Mississippi in 2010 and 2011 . Harvested roots were stored without curing at $65{ }^{\circ} \mathrm{F}\left(18.3{ }^{\circ} \mathrm{C}\right)$ and $70 \%$ to $80 \%$ relative humidity for 1 to 2 mo. until evaluation.

\begin{tabular}{|c|c|c|c|c|c|c|c|c|c|c|c|c|}
\hline \multirow[b]{3}{*}{$\begin{array}{l}\text { Ethephon rate } \\
(\text { oz/acre })^{\mathrm{z}}\end{array}$} & \multicolumn{6}{|c|}{2010} & \multicolumn{5}{|c|}{2011} & \multirow{3}{*}{$\begin{array}{c}2 \text { years } \\
\begin{array}{c}\text { Total } \\
(\%)\end{array}\end{array}$} \\
\hline & \multicolumn{5}{|c|}{ Field location $^{\mathrm{y}}$} & \multirow[b]{2}{*}{$\begin{array}{c}\text { Total } \\
(\%)\end{array}$} & \multicolumn{4}{|c|}{ Field location } & \multirow[b]{2}{*}{$\begin{array}{c}\text { Total } \\
(\%)\end{array}$} & \\
\hline & $\begin{array}{c}\text { Bellef. } \\
(\%)\end{array}$ & $\begin{array}{c}\text { Vard. } 1 \\
(\%)\end{array}$ & $\begin{array}{c}\text { Vard. } 2 \\
(\%)\end{array}$ & $\begin{array}{c}\text { Road } 33 \\
(\%)\end{array}$ & $\begin{array}{c}\text { Res. Sta. } \\
(\%)\end{array}$ & & $\begin{array}{c}\text { Houlka } \\
(\%)\end{array}$ & $\begin{array}{c}\text { Vard. } 1 \\
(\%)\end{array}$ & $\begin{array}{c}\text { Vard. } 2 \\
(\%)\end{array}$ & $\begin{array}{c}\text { Res. Sta. } \\
(\%)\end{array}$ & & \\
\hline 0 & 0.0 & $0.0 \mathrm{a}^{\mathrm{x}}$ & $0.0 \mathrm{a}$ & 0.0 & 0.0 & $0.0 \mathrm{a}$ & $0.0 \mathrm{a}$ & 4.6 & $0.0 \mathrm{a}$ & $0.7 \mathrm{a}$ & $1.0 \mathrm{a}$ & $0.4 \mathrm{a}$ \\
\hline 12 & & & $2.3 \mathrm{ab}$ & 0.7 & & $1.5 \mathrm{ab}$ & $3.0 \mathrm{a}$ & 10.9 & $4.7 \mathrm{ab}$ & & $5.6 \mathrm{~b}$ & $3.6 \mathrm{~b}$ \\
\hline 24 & 2.5 & $9.8 \mathrm{~b}$ & $5.7 \mathrm{~b}$ & 1.8 & 1.6 & $3.8 \mathrm{~b}$ & $11.4 \mathrm{~b}$ & 9.9 & $13.3 \mathrm{~b}$ & $13.8 \mathrm{~b}$ & $12.5 \mathrm{c}$ & $7.6 \mathrm{c}$ \\
\hline Correlation $(r)$ & & & 0.69 & & & 0.54 & 0.85 & & 0.89 & & 0.78 & 0.60 \\
\hline
\end{tabular}

${ }^{2} \mathrm{loz} /$ acre $=70.0532 \mathrm{~g} \cdot \mathrm{ha}^{-1}$

Bellef $=$ Bellefontaine, Vard $=$ Vardaman, Res. Sta $=$ Research Station $($ Table 1 )

${ }^{x}$ Means within columns followed by different letters are significantly different from each other by Tukey's multiple range test at $P \leq 0.05$.

$\mathrm{NS},{ }^{*},{ }^{* *},{ }^{* *}$ Nonsignificant and significant at $P \leq 0.05,0.01$, and 0.001 , respectively. 
was significantly higher in 2011 than 2010 suggesting that environmental conditions may also be a factor influencing the incidence of this disorder. In contrast, there were no differences in unrestricted end rot incidence among treatments in individual fields except at Vardaman 2 in 2010 (Table 3 ). End rot incidence ranged between $0 \%$ and $23.3 \%$ among treatments and fields. Furthermore, when fields were pooled together, there was no difference between ethephon applications and the untreated control. The interaction between fields and treatments and the poor correlation of the field average indicate that there was not a consistent association between ethephon application and end rot incidence in this study.

Pathogenic fungi have been inconsistently isolated from storage roots with tip rot symptoms (da Silva and Clark, 2012; Stokes et al., 2012). The most abundant fungi isolated from tip rot lesions were Macrophomina phaseolina, Lasiodiplodia theobromae, Diaporthe phaseolorum, and several Fusarium species, including pathogenic and nonpathogenic species. Pathogenic and nonpathogenic bacteria have also been isolated from tip rot lesions (Stokes et al., 2012). However, it is yet to be determined whether these organisms are primary pathogens, endophytes that are present coincidently, or secondary opportunistic invaders. These isolated pathogenic fungi commonly induce nonrestricted rots in sweetpotato storage roots (Clark, 1992; Clark et al., 2013). Although results of this study suggest that preharvest applications of ethephon trigger responses conducive to the tip rot disorder, it is possible that ethylene effects allow pathogenesis by microbes that otherwise would not have affected the storage root.

E THEPHON RA TE A N D APPLICATION TIME. A relationship between ethephon rate and tip rot incidence, but not with end rot incidence, was found in the rate trial (Figs. 2 and $3)$. In general, tip rot incidence increased as ethephon rate increased, but the pattern differed depending on the time between application and harvest (Fig. 2). The average tip rot incidence ranged from less than $0.5 \%$ in roots from nontreated defoliated plants up to $5.7 \%$ in roots from plants treated with ethephon at $36 \mathrm{oz} /$ acre $7 \mathrm{DBH}$. There were no differences in tip rot incidence among $\mathrm{DBH}$ in the untreated/defoliated or between ethephon at 12 and $36 \mathrm{oz} /$ acre. Similarly, the incidences at $12 \mathrm{oz} /$ acre were not different from the untreated defoliated for all DBH. A different pattern was observed when ethephon was applied $1 \mathrm{DBH}$ : tip rot incidence only increased at the highest ethephon rate $(36 \mathrm{oz} / \mathrm{acre})$ and not at $24 \mathrm{oz} /$ acre as when applied 3 and 7 $\mathrm{DBH}$ (Fig. 2). Therefore, the ethephon effect on tip rot at $24 \mathrm{oz} /$ acre was influenced by the time between application and harvest: $3 \mathrm{~d}$ or more was necessary to trigger the response conducive to the tip rot disorder. Nonetheless, the incidence trend was well correlated $(r=0.75,0.85$, and 0.83 ) with ethephon rate when applied at 1,3 , and $7 \mathrm{DBH}$, respectively. These results also support the hypothesis that ethephon-induced stress triggers physiological responses that result in an increase in the tip rot disorder. Moreover, the results suggest that the response depends on ethephon concentration and the interval between application and harvest.

Similar to the field studies, there were no differences among DBH in the incidence of unrestricted end rot in storage roots from ethephontreated plants (Fig. 3). The incidence of unrestricted end rot, however, was higher in roots from untreated plants when they were defoliated/devined (with a two-row flail mower/deviner) at harvest (data not presented) or 1 $\mathrm{DBH}(2.8 \%)$ in comparison with 3 $\mathrm{DBH}(0.2 \%)$ and $7 \mathrm{DBH}(0.5 \%)$. These results suggest that defoliation/ devining 3 to $7 \mathrm{DBH}$ also induces changes that may reduce the susceptibility to pathogen activity. Defoliation/ devining has been reported to induce changes in the storage roots that results in skin set and reduced skinning incidence (LaBonte and Wright, 1993). In addition, recent studies have shown an increase in total phenolics as well as lignin/suberin content in the skin of storage roots from defoliated/devined plants (Wang et al., 2012). These changes might be involved in reduced pathogen activity, but further studies are necessary to confirm this finding.

Ethephon induces leaf senescence and stress messengers produced during this process may activate mechanisms conducive to the tip rot disorder. Among the physiological changes that occur during leaf senescence, additional stress signals such as reactive oxygen species (ROS) are produced by degradation of the photosynthetic apparatus. ROS have been reported to induce synthesis of jasmonic acid (JA) before cell death (He et al., 2002; Lim

Table 3. Percent incidence of unrestricted end rot in sweetpotato roots in response to preharvest applications of ethephon in Mississippi in 2010 and 2011 . Harvested roots were stored without curing at $65{ }^{\circ} \mathrm{F}\left(18.3{ }^{\circ} \mathrm{C}\right)$ and $70 \%$ to $80 \%$ relative humidity for 1 to 2 mo. until evaluation.

\begin{tabular}{|c|c|c|c|c|c|c|c|c|c|c|c|c|}
\hline \multirow[b]{3}{*}{$\begin{array}{l}\text { Ethephon rate } \\
(\text { oz/acre })^{\mathrm{z}}\end{array}$} & \multicolumn{6}{|c|}{2010} & \multicolumn{5}{|c|}{2011} & \multirow{3}{*}{$\begin{array}{c}\frac{2 \text { years }}{\text { Total }} \\
(\%)\end{array}$} \\
\hline & \multicolumn{5}{|c|}{ Field location $^{\mathrm{y}}$} & \multirow[b]{2}{*}{$\begin{array}{c}\text { Total } \\
(\%)\end{array}$} & \multicolumn{4}{|c|}{ Field location } & \multirow[b]{2}{*}{$\begin{array}{c}\text { Total } \\
(\%)\end{array}$} & \\
\hline & $\begin{array}{c}\text { Bellef. } \\
(\%)\end{array}$ & $\begin{array}{c}\text { Vard. } 1 \\
(\%)\end{array}$ & $\begin{array}{c}\text { Vard. } 2 \\
(\%)\end{array}$ & $\begin{array}{c}\text { Road } 33 \\
(\%)\end{array}$ & $\begin{array}{c}\text { Res. Sta. } \\
(\%)\end{array}$ & & $\begin{array}{c}\text { Houlka } \\
(\%)\end{array}$ & $\begin{array}{c}\text { Vard. I } \\
(\%)\end{array}$ & $\begin{array}{c}\text { Vard. } 2 \\
(\%)\end{array}$ & $\begin{array}{c}\text { Res. Sta. } \\
(\%)\end{array}$ & & \\
\hline 0 & 12.9 & 0.0 & $0.6 \mathrm{a}^{\mathrm{x}}$ & 1.5 & 6.7 & $4.4 \mathrm{ab}$ & 0.0 & 2.7 & 2.0 & 1.2 & 1.4 & $3.1 \mathrm{ab}$ \\
\hline 12 & & & $1.5 \mathrm{a}$ & 0.0 & & $0.7 \mathrm{a}$ & 0.0 & 1.3 & 6.7 & & 2.8 & $1.8 \mathrm{a}$ \\
\hline 24 & 23.3 & 0.0 & $7.7 \mathrm{~b}$ & 1.0 & 9.0 & $8.3 \mathrm{~b}$ & 0.0 & 6.9 & 1.0 & 0.6 & 1.5 & $5.4 \mathrm{~b}$ \\
\hline
\end{tabular}

${ }^{\mathrm{z}} 1 \mathrm{oz} / \mathrm{acre}=70.0532 \mathrm{~g} \cdot \mathrm{ha}^{-1}$

${ }^{y}$ Bellef. $=$ Bellefontaine, Vard. $=$ Vardaman, Res. Sta. $=$ Research Station $($ Table 1$)$.

${ }^{x}$ Means within columns followed by different letters are significantly different from each other by Tukey's multiple range test at $P \leq 0.05$

NS, *, and ${ }^{* *}$ Nonsignificant and significant at $P \leq 0.05$ and 0.001 , respectively. 


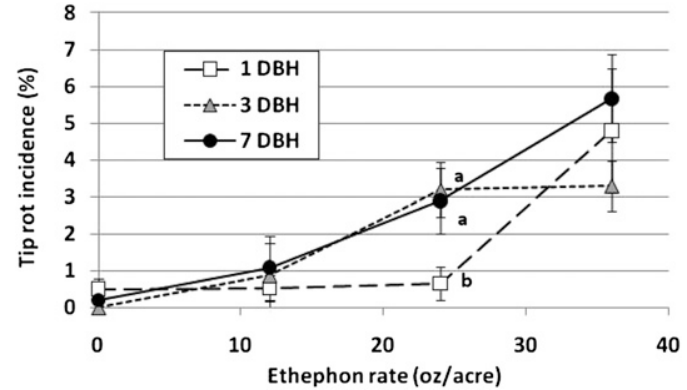

Fig. 2. Tip rot (restricted rot) incidence in 'Beauregard' (B-14) sweetpotato in response to ethephon-induced stress: effect of ethephon rate and time of application. Treatments consisted of preharvest defoliation/devining (ethephon at $0 \mathrm{oz} /$ acre) and foliar applications of ethephon at rates of 12, 24, and $36 \mathrm{oz} /$ acre. Treatment time for defoliation/devining (ethephon at $0 \mathrm{oz} / \mathrm{acre}$ ) and ethephon applications were at 1,3 , and $7 \mathrm{~d}$ before harvest (DBH). Ethephon-treated plots were defoliated/devined on the day of harvest. Tip rot incidence was evaluated 2 months after harvest. Each point is the mean of four replications. Bars represent the SE of the mean. Means at ethephon rate of $24 \mathrm{oz} /$ acre with different letters are significantly different from each other by Tukey's multiple range test at $P \leq 0.05$. Correlation $(r)$ between tip rot incidence and ethephon rate at 1,3 , and $7 \mathrm{DBH}$ was $0.75,0.85$, and 0.83 , respectively; $1 \mathrm{oz} /$ acre $=70.0532 \mathrm{~g} \cdot \mathrm{ha}^{-1}$.

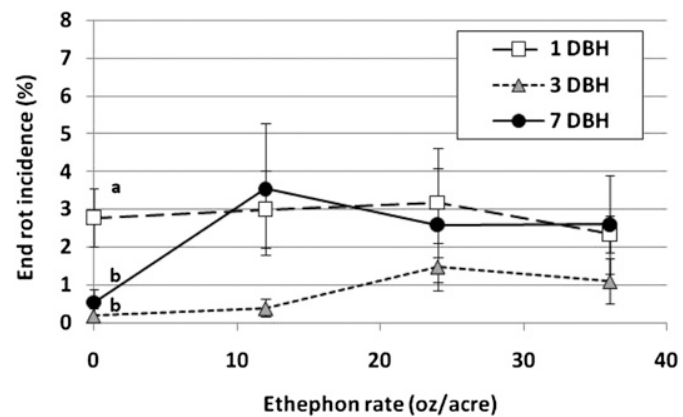

Fig. 3. Unrestricted end rot incidence in 'Beauregard' (B-14) sweetpotato in response to ethephon-induced stress: effect of rate and time of application. Treatments consisted in preharvest defoliation/devining (ethephon at $0 \mathrm{oz} / \mathrm{acre}$ ) and applications of ethephon at rates of 12,24 , and $36 \mathrm{oz} /$ acre. Treatment time for defoliation/devining (ethephon at $0 \mathrm{oz} / \mathrm{acre}$ ) and ethephon applications were at 1 , 3 , and $7 \mathrm{~d}$ before harvest (DBH). Ethephon-treated plots were defoliated/devined on the day of harvest. End rot incidence was evaluated 2 months after harvest. Each point is the mean of four replications. Bars represent the SE. Means at ethephon rate of $0 \mathrm{oz} /$ acre (defoliation/devining) with different letters are significantly different from each other by Tukey's multiple range test at $P \leq 0.05 ; 1 \mathrm{oz} / \mathrm{acre}=70.0532 \mathrm{~g} \cdot \mathrm{ha}^{-1}$. et al., 2007). JA levels are four times higher in senescing arabidopsis leaves than in nonsenescing ones. Salicylic acid (SA) also increases in the initial stages of common sage (Salvia officinalis) leaf senescence when induced by water stress conditions (Abreu and Munné-Bosch, 2008). JA, ethylene, and SA have been reported to be involved in resistance and programmed cell death [PCD (García-Heredia et al., 2008; Greenberg, 1997; Reinbothe et al., 2009)]. These stress messengers can reach the roots and activate defense responses, and in the case of JA, induce PCD when interacting with ethylene. Therefore, PCD might be involved in the tip rot disorder. In addition, a recent study found that total phenolics increased in sweetpotato storage roots from ethephon-treated plants (Arancibia et al., 2011). Phenolics are known to play a role in the defense system of sweetpotato (Harrison et al., 2008; Peterson et al., 2003). Therefore, an increase in phenolics is evidence of activation of the defense system that might be involved in restricting the advance of pathogen, growth of endophytes, or both.

Curing. The effect of curing immediately after harvest on the incidence of tip and end rot on storage roots from ethephon-treated plants also was evaluated in 2010 and 2011 (Table 4). Since curing had the same effect on reducing tip and end rot incidence regardless of ethephon rate, data were pooled together for analysis. The incidence of tip and end rot was reduced in cured storage roots from almost all fields and the overall effect for all fields both years was highly significant. Curing reduced tip and end rot incidence from $6.4 \%$ to $1.1 \%$ and from $4.0 \%$ to $0.6 \%$,

Table 4. Percent incidence of tip rot and unrestricted end rot in sweetpotato roots from ethephon-treated plants after curing in 2010 and 2011 . Storage roots were cured at $85{ }^{\circ} \mathrm{F}\left(29.4^{\circ} \mathrm{C}\right)$ and $80 \%$ to $85 \%$ relative humidity for $7 \mathrm{~d}$ and then stored with noncured roots at $65^{\circ} \mathrm{F}\left(18.3^{\circ} \mathrm{C}\right)$ and $70 \%$ to $80 \%$ relative humidity for 1 to 2 mo. until evaluation.

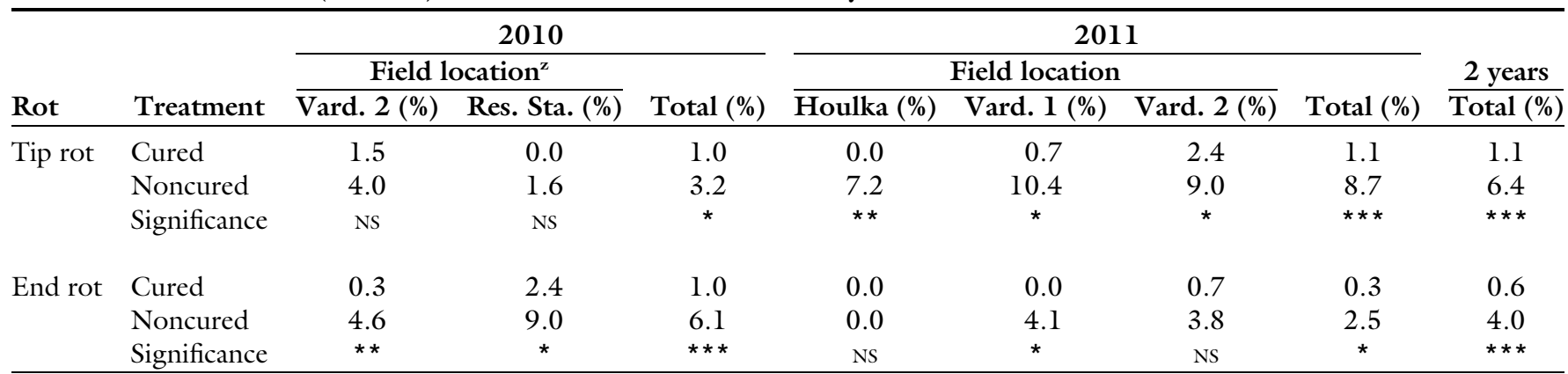

${ }^{z}$ Vard. = Vardaman, Res. Sta. $=$ Research Station $($ Table 1$)$.

$\mathrm{NS},{ }^{*}{ }^{* *}$, and ${ }^{* * *}$ Nonsignificant and significant at $P \leq 0.05,0.01$ and 0.001 , respectively. 
respectively. Curing has been recommended based on the dogma that curing promotes rapid wound healing and thereby prevents entry of the pathogens. However, recent studies suggest that many of the fungi isolated from end or tip rots are also endophytic and may be present inside the roots before curing (da Silva and Clark, 2012; Stokes et al., 2012). Since curing promotes rapid wound periderm formation, resulting in reduced water loss, the effect of curing on reduced tip/end rot development may also be due to indirect physiological effects of the process. At optimal curing temperature, metabolic processes may prevent expression of the tip rot syndrome and/or enhance the healing process and other defense mechanisms preventing/restricting the advance of the pathogens. In contrast, at noncuring temperature conditions, tip rot is expressed and/or pathogens are able to enter and grow before wound healing and other defense mechanisms are fully activated. Therefore, curing sweetpotato immediately after harvest is recommended to reduce tip rot in addition to other postharvest diseases (Clark, 1992; Clark et al., 2013; Edmunds et al., 2008; Thompson et al., 2002).

In conclusion, sweetpotato tip rot is associated with ethephoninduced stress and preharvest foliar applications of ethephon enhance the incidence. The evidence in this study supports the hypothesis that ethephoninduced stress triggers physiological responses that result in the tip rot disorder. Further research is needed to determine the role that microorganisms may play in the development of this syndrome. Finally, curing at optimal conditions appears to be the best option to reduce the incidence of postharvest diseases/disorder that would improve pack-out efficiency in sweetpotato production.

\section{Literature cited}

Abeles, F.B., P.W. Morgan, and M.E. Salveit. 1992. Ethylene in plant biology. Academic Press, San Diego, CA.
Abreu, M.E. and S. Munné-Bosch. 2008. Salicylic acid may be involved in the regulation of drought-induced leaf senescence in perennials: A case study in field-grown Salvia officinalis L. plants. Environ. Expt. Bot. 64:105-112.

Arancibia, R.A., J.L. Main, and X. Wang. 2011. Preharvest applications of ethephon increases phenolics and skinning tolerance in sweetpotato. HortScience 46:S297. (abstr.).

Clark, C.A. 1992. Postharvest diseases of sweet potatoes and their control. Postharvest News Info. 3:75N-79N.

Clark, C.A., D.M. Ferrin, T.P. Smith, and G.J. Holmes (eds.). 2013. Compendium of sweetpotato diseases, pests, and disorders. 2nd ed. APS Press, St. Paul, MN.

da Silva, W.L. and C.A. Clark. 2012. Infection of sweetpotato by fungal end rot pathogens prior to harvest. Phytopathology 102:S2.2-S2.3. (abstr.).

Dittmar, P.J., K.M. Jennings, D.W Monks, and J.R. Schultheis. 2010. Determining the effect of ethylene on internal black marbling expression in sweetpotato. HortScience 45:488-489. (abstr.).

Edgerton, L.J. and A.H. Hatch. 1972. Absorption and metabolism of $14 \mathrm{C}(2$ chloroethyl) phosphonic acid in apples and cherries. J. Amer. Soc. Hort. Sci. 97:112-115.

Edmunds, B., M. Boyette, C. Clark, D. Ferrin, T. Smith, and G. Holmes. 2008. Postharvest handling of sweetpotatoes. 7 Jan. 2013. <http://www.cals.ncsu.edu/ plantpath/extension/commodities/ sweetpotatoes_postharvest.pdf.

García-Heredia, J.M., M. Hervás, M.A. De la Rosa, and J.A. Navarro. 2008. Acetylsalicylic acid induces programmed cell death in arabidopsis cell cultures. Planta 228:89-97.

Greenberg, J.T. 1997. Programmed cell death in plant-pathogen interactions. Annu. Rev. Plant Physiol. Plant Mol. Biol. 48:525-545.

Harrison, H.F., T.R. Mitchell, J.K. Peterson, W.P. Wechter, G.F. Majetich, and M.E. Snook. 2008. Content of caffeoylquinic acid compounds in the storage roots of sixteen sweetpotato genotypes and their potential biological activity. J. Amer. Soc. Hort. Sci. 133:492-500.
He, Y., H. Fukushige, D.F. Hildebrand, and S. Gan. 2002. Evidence supporting a role of jasmonic acid in arabidopsis leaf senescence. Plant Physiol. 128:876-884.

LaBonte, D.R. and M.E. Wright. 1993. Image analysis quantifies reduction in sweetpotato skinning injury by preharvest canopy removal. HortScience 28:1201.

Lim, P.O., H.G. Nam, and H.J. Kim. 2007. Leaf senescence. Annu. Rev. Plant Biol. 58:115-136.

Peterson, J.K., H.F. Harrison, D.M. Jackson, and M.E. Snook. 2003. Biological activities and contents of scopolin and scopoletin in sweetpotato clones. HortScience 38:1129-1133.

Reinbothe, C., A. Springer, I. Samol, and S. Reinbothe. 2009. Plant oxylipins: Role of jasmonic acid during programmed cell death, defence and leaf senescence. FEBS J. 276:4666-4681.

Schultheis, J.R., S.M. Blankenship, D.W. Monks, and M.D. Boyette. 2000. Preharvest methods to reduce skinning in 'Beauregard' sweetpotato. HortScience 35:444. (abstr.).

Stokes, C.E., S.W. Woolfolk, R.A. Arancibia, and R.E. Baird. 2012. Diversity, densities, and distribution of microbial communities in sweetpotato end/tip rot diseases. HortScience 47:S47-S48. (abstr.).

Thompson, P., M. Williams, J. Byrd, J. Thomas, D. Parvin, and F. Killebrew. 2002. Commercial sweetpotato production in Mississippi. Mississippi State Univ. Ext. Serv. Publ. 1678.

U.S. Department of Agriculture. 2012. Crop production 2011 summary. 7 Jan. 2013. <http://usda01.library.cornell.edu/ usda/current/CropProdSu/CropProdSu01-12-2012.pdf.

Young, R.H. and O.L. Jahn. 1975. The fate of 1,2-14C-(2-chloroethyl)phosphonic acid in citrus. J. Amer. Soc. Hort. Sci. 100:496-499.

Wang, X., R.A. Arancibia, J.L. Main, and M. Shankle. 2012. Pre-harvest application of ethephon enhances skin lignification and increases the force required to peel sweetpotato storage roots. HortScience 47:S191. (abstr.). 